\title{
THE LEGAL FRAMEWORK FOR CORPORATE LIABILITY FOR HOMICIDE: THE EXPERIENCE IN NIGERIA AND THE UNITED KINGDOM
}

\author{
Akanbi, Khairat Oluwakemi*
}

\begin{abstract}
In recent times, corporate homicide has become an increasingly global phenomenon. These global incidences make it imperative to have a legal framework for holding corporations liable for deaths either of employees or members of the public that occur as a result of their activities. The challenge however is in applying the traditional criminal law elements of actus reas and mens rea to a corporation, since the criminal law had developed with the natural person in mind. The aim of this paper is to examine the legal framework for corporate liability for homicide sharing the experience in Nigeria and the UK. The paper discusses the application of criminal law elements of actus reas and mens rea to a corporate body in order to justify corporate liability for homicide. It also examines the Corporate Manslaughter and Corporate Homicide Act 2007 of the UK which is the first legislation on corporate homicide together with the position in Nigeria. The paper finds that the legal framework in Nigeria is inadequate to secure corporate liability for homicide. The UK provisions can thus serve as a useful model in this regard.
\end{abstract}

Lecturer, Department of Business Law, Faculty of Law, University of Ilorin, Nigeria and Doctoral Research Candidate in Law, International Islamic University Malaysia. 
Keywords: Corporate homicide; criminal liability; legal framework; Nigeria; United Kingdom.

\title{
KERANGKA UNDANG-UNDANG BAGI TANGGUNGAN LIABILITI KORPORAT UNTUK KES-KES HOMISID: PENGALAMAN DI NIGERIA DAN UNITED KINGDOM
}

\begin{abstract}
ABSTRAK
Sejak kebelakangan ini, kes-kes homisid yang melibatkan syarikat korporat telah meningkat menjadi satu fenomena sejagat. Kejadian-kejadian yang berlaku di serata dunia ini telah mewujudkan keperluan untuk mengadakan suatu kerangka undang-undang bagi meletakkan tanggungan liabiliti terhadap perbadanan-perbadanan atas kematian samada pekerja-pekerja mereka atau orang-orang awam berpunca daripada aktiviti-aktiviti yang mereka jalankan. Walaubagaimanapun, adalah menjadi satu cabaran untuk menggunapakai unsur actus reus dan mens rea yang terdapat di dalam undang-undang jenayah tradisional ke atas sesebuah perbadanan kerana ia merupakan satu entiti tiruan sedangkan undang-undang jenayah dibangunkan dengan mengambil orang semulajadi sebagai subjek asasnya. Oleh itu, tujuan kertas kajian ini adalah untuk melihat kerangka undang-undang berhubung tanggungan liabiliti korporat dalam kes-kes homisid dengan berkongsi pengalaman di Nigeria dan United Kingdom. Untuk mencapai matlamat ini, kertas ini membincangkan pemakaian unsur-unsur actus reus dan mens rea yang terdapat di dalam undang-undang jenayah ke atas sebuah badan korporat bertujuan untuk menjustifikasikan tanggungan liabiliti korporat di dalam kes-kes homisid. Kertas ini juga turut mengkaji peruntukan undang-undang berkaitan di United Kingdom iaitu Corporate Manslaughter and Corporate Homicide Act 2007 yang merupakan undang-undang pertama mengenai homisid korporat, juga melihat kedudukan peruntukan undangundang seumpamanya di Nigeria. Kajian ini mendapati bahawa kerangka undang-undang berkaitan di Nigeria
\end{abstract}


adalah tidak mencukupi untuk mengenakan liabiliti korporat ke atas sesebuah perbadanan dalam kes-kes pembunuhan. Oleh yang demikian, peruntukan undangundang di United Kingdom adalah sangat berguna untuk dijadikan sebagai model yang berkaitan dengannya.

Kata kunci: Homisid korporat; liability jenayah; kerangka undang-undang; Nigeria; United Kingdom.

\section{INTRODUCTION}

Corporate homicide is a global phenomenon especially in the area of unsafe goods and services and work place related deaths. There have been global incidences of death occurring as a result of some activities of corporations. For example, in the United Kingdom (UK), in 1987, the Herald of Free Enterprise ferry collapsed leading to the death of about one hundred and ninety three people on board. In the same year, there was the King's Cross Station fire also in the UK which killed thirty one people. Similarly, a gas explosion caused by leaking pipes killed four people in their home in Scotland in 2001. In 2005, the BP American refinery exploded in the United States killing fifteen people. In Australia, there was the Esso Longford mining explosion in1998. In Malaysia, a bus accident in Muar killed nine people in 2008. Also, in Nigeria, in June 2012, a commercial plane crashed in Lagos, killing more than one hundred and fifty people. Most recently, in April, 2013, there was a garment factory accident in Dhaka, Bangladesh which killed more than a thousand people.

In many cases of corporate homicide, corporations have escaped criminal liability. This is despite the fact that the locus classicus decision in Salomon v. Salomon \& Co., ${ }^{1}$ which says that a corporation upon incorporation assumes a legal personality and status in law separate from that of its members, can be regarded as the foundation of corporate criminal liability generally. This is because it is when the corporation is treated as a person in law, that it becomes a recipient of rights and bearer 
of duties. ${ }^{2}$ The capacity to sue and be sued therefore is one of the effects of incorporation.

Corporate criminal liability started with non-feasance offences ${ }^{3}$ and was later extended to malfeasance offences but essentially, this was limited to strict liability statutory offences. ${ }^{4}$ However, with industrialisation and the continuous growth of corporations with the attendant increase in corporate crimes, it became inevitable to extend the criminality of corporations beyond that of strict liability malfeasance cases. Yet, central to criminal liability are the twin ingredients of actus reas and mens rea, so much so that before there can be criminal responsibility, the two ingredients must exist. Therefore, the challenge to corporate criminal liability is in attributing the twin criminal law elements to an artificial person like a corporation since the criminal law developed with the natural person in mind.

Against the above backdrop, the objective of this paper is to examine the adequacy or otherwise of the legal framework for corporate liability for homicide with reference to the positions in Nigeria and the UK. The paper discusses the application of the criminal law elements of actus reas and mens rea to a corporate body in order to justify corporate liability for homicide, examines and the Corporate Manslaughter and Corporate Homicide Act 2007 of the UK which is the first legislation on corporate homicide.

\section{THE CONCEPT OF CORPORATE HOMICIDE}

Homicide generally is the killing of one person by another. ${ }^{5}$ Corporate homicide will therefore mean a situation where the acts or omission causing

2 This decision has since been incorporated into the legal jurisprudence of most countries through both case law and statutes.

3 In $R$ v. Birmingham \& Gloucester Railway Coy Ltd (1842) 2 QB 114 ER, 492, a corporation was convicted for failing to fulfill a statutory duty.

$4 \quad$ The scope of corporate criminal liability was considerably extended by cases like $R$ v. ICR Haulage (1944) 1KB 551, Moore v. Bresler (1944) 2 ALL ER 515, DPP v. Kent \& Sussex Contractors (1944) 1 KB 146.

$5 \quad$ C.M.V Clarkson, H.M Keating and S.R. Cunningham, Criminal Law (London, Sweet and Maxwell 2010) 660. 
death occurred as a result of the systemic misconduct of a corporation, and the corporation is the truly blameworthy party and not the individual members of the corporation. An example is the collapse of the Herald of Free Enterprise ferry in 1987 which killed close to two hundred people. The ferry sank within minutes of leaving Zeebrugge harbour because it sailed with her bow doors open and trimmed by the head so that within minutes of sailing, water entered the deck through the open doors leading to the capsize of the ferry. The Report of the investigation concluded that the company had a culture of sloppiness. ${ }^{6}$ Workers engaged to oversee the security aspects of the ferry did not do their work. Specifically, the assistant bosun who was supposed to shut the doors failed to do so, while the chief officer who was supposed to supervise to ensure that the bosun did his work also failed to discharge his duty. ${ }^{7}$ Clearly, the ferry sank because the company had a culture of negligence and lacked a mechanism in place to ensure that workers do their job.

Similarly, there was a plane crash in Lagos, Nigeria in 2012 which killed over one hundred and fifty people. The crash has been attributed to negligence on the part of the commercial airline company as there had been near crash experiences involving non-operational landing gears from passengers before the crash. ${ }^{8}$ The gas explosion in Scotland which killed a family of four in 2001 as a result of an explosion caused by leaking pipes took place as a result of the negligence of the gas company. ${ }^{9}$

The above instances of negligence or recklessness on the part of the corporations mean that there is a flow in the relationship between a corporation and its employees and the public at large. The corporation therefore is the proper party to be held accountable for the deaths. Nevertheless, there are legal challenges in bringing a corporation to book. The next segment of this paper discusses the challenges.

\footnotetext{
$6 \quad$ H.M Coroner for Kent Ex. P. Spooner (1989) 88 Cr. App. R. 207. Amanda Pinto \& Martin Evans Corporate Criminal Liability (London, Sweet \& Maxwell 2003) 220.

8 Interview with Godswill Akpabio, the Executive Governor of AkwaIbom State South of Nigeria in Vanguard Newspapers, 21 $1^{\text {st }}$ July, 2012. 


\section{CHALLENGES IN CORPORATE HOMICIDE}

The Latin maxim actus non facitreum nisi mens sit rea accurately capture the basis of criminal liability. The challenge of corporate homicide is in applying the twin ingredients of actus reas and mens rea to a corporation being an artificial entity. In fact, one of the earliest challenges to corporate criminal liability was in attributing a corporate body with actus reas and mens rea. ${ }^{10}$

The issues to be addressed are:

1) How to determine the actusreus of a corporation.

2) How to determine the corporate mens rea.

\section{Actus reas:}

The actus reas is the physical manifestation of the crime. Therefore, the first requirement for criminal culpability is the actus reas which can be in form of acts or omission. However, determining the acts or omission of a corporation is peculiar because the corporation is a legal creation and cannot act physically by itself but only through its agents and officers. Therefore, the actus reas of a corporation can be found in the acts or omissions which are clearly regarded as the acts of a corporation.

Statutes usually provide for acts that should be regarded as the acts of a corporation. For example, the Companies and Allied Matters Act of Nigeria provides ${ }^{11}$ that actions of the members in general meeting, the managing director and the board of directors done while carrying out the usual business of the company will be construed as acts of the corporation itself. It provides further ${ }^{12}$ that acts of officers and agents of the company will be deemed to be that of the company if the company through its members in general meeting, the managing director or through

\footnotetext{
$10 \quad$ V.S Khanna, (1996), “Corporate Criminal Liability: What Purpose Does it Serve? Harvard Law Review, 1479.

11 Section 65, Companies and Allied Matters Act, Cap C20, L.F.N 2004.

12 Section 66.
} 
the board of directors had expressly or implicitly authorised the officer or the agent to act. ${ }^{13}$

In the same vein, the Australian Criminal Code provides ${ }^{14}$ that the physical elements of a crime will be attributed to the corporation ${ }^{15}$ if the crime was committed by an employee, agent or officer of the corporation within the actual or apparent authority or scope of employment. ${ }^{16}$

The actus reas of a corporation therefore will include acts done by officers and agents of the corporation while carrying on the usual business of the corporation.

\section{Mens Rea}

Mens rea is the mental element of an offence and it constitutes the greatest challenge to holding corporations liable for homicide. This is because a corporation is an artificial entity and it seemed difficult to attach a mental element to an artificial entity which is ordinarily incapable of any emotive feeling.

Yet, the courts have over time attempted to capture the corporate mens rea by using different methods. The English courts had used the civil law doctrine of vicarious liability by holding a corporation vicariously liable for the mens rea of its officers. For example, in the case of Mousell Brothers Ltd v. London and North -Western Rly Co. ${ }^{17}$ it was held that the corporation could be vicariously liable for the acts of its employees. This approach is also in use in South Africa through the statutory provisions of the Criminal Procedure Act ${ }^{18}$ which provides ${ }^{19}$ that a corporate body is vicariously liable for acts done by or on instruction or through implied or express permission of its directors or servants. ${ }^{20}$ However, the vicarious

\footnotetext{
$13 \quad$ Adeniji v. State (1992) 4 NWLR (pt. 597) 53 at 66.

$14 \quad$ Section 12.2, Criminal Code Act 1995.

15 The word corporate body is used in the Act.

16 Section 12.2, Criminal Code Act.

$17 \quad$ (1972) 2 KB 836.

$18 \quad$ Act 511977.

19 Section 332.

20 The statutory provision of the Criminal Procedure Act even extends
} 
liability method does not accurately capture the corporate mens rea. This is because it is against the individualistic notion of the criminal law to hold a "person" liable for the wrong of another person. Secondly, it seems to render the issue of mens rea irrelevant which is at the cornerstone of criminal responsibility. This is because applying vicarious liability to corporate criminal liability renders a corporation guilty irrespective of the fact that it had not the mens rea to commit the act constituting the offence or even of the fact that the act itself might have been committed contrary to corporate policy. ${ }^{21}$

The principle of respondeat superior has also been used to justify holding a corporation liable for the mens rea of its officers or agents. It was adapted to the criminal law for the first time by the American Court in the case of New York Central and Hudson River v. United States. ${ }^{22}$ In arriving at the decision, the court held that since the corporation can only act through its officers and agents, then it should in the same vein be liable for the acts of its agents who have the authority to act in a particular manner. Under this theory, three factors must exist. The first is that there must be the commission of a crime by an agent of the corporation. Secondly, the crime must be committed in the course of employment and lastly, such crime must be done with the intent to benefit the corporation. In applying this theory, the court considers both the apparent and express authority of the employee. ${ }^{23}$ In United States $v$. Hilton Hotels Corporation, ${ }^{24}$ Hilton hotel was held liable despite evidence that the responsible employee acted contrary to the corporation's instructions. ${ }^{25}$ The corporation is held liable even if it had in fact received no benefit from the crime committed so long as the employee intended to benefit the corporation. ${ }^{26}$

\footnotetext{
the liability of the corporation beyond acts done within the scope of employment. Nana p. 94. Africa: the need to look beyond vicarious liability,” J.A.L, 55 (1) p. 101.

25 The rationale given for ascribing liability to the company was that the corporation did not take stringent measures to ensure that its instructions were complied with. 
Like the vicarious liability method, this approach is against the individualistic notion of criminal law and may in fact disregard the mens rea because the corporation is held liable despite the fact that the agent or employee acted contrary to the corporation's instructions.

The identification method has also been used to determine the corporate mens rea. It is the most prominent method of determining the corporate mens rea having been adopted in various Commonwealth countries like Malaysia, Nigeria and Australia. It was introduced into criminal law by the English courts in a series of cases that were decided in 1944. ${ }^{27}$ This method locates the corporate mens rea in a person who is the directing mind of the corporation. ${ }^{28}$ In D.P.P v. Kent, ${ }^{29}$ it was held thus:

"It is true that a corporation can only have knowledge and form an intention through its human agents, but circumstances may be such that the knowledge and intention of the agent must be imputed to the body corporate...If the responsible agent of a company, acting within the scope of its authority, puts forward on its behalf a document which he knows to be false and by which he intends to deceive, I apprehend that ... his knowledge and intention must be imputed to the company."

In the subsequent case of Bolton (Engineering) Co. Ltd. v. Graham and Sons, ${ }^{30}$ it was held by Lord Denning LJ:

"A company may in many ways be likened to a human body. It has a brain and nerve centre which controls

2D 174, 204 (3d Cir. 1970), cert. denied, 401 U.S. 94 (1971).

$27 \quad$ D.P.P v. Kent \& Sussex Contractors Ltd. (1944) 1 K.B 146, R v. I.C.R Haulage Ltd (1944) K.B 551 and Moore v. Bresler Ltd (1944) 2 K.B 515.

$28 \quad$ The courts were probably influenced by the decision in the civil case of Lennards Carrying Co v. Asiatic Petroleum Co Ltd (1915) A.C 705 HL.

29 Supra.

$30 \quad$ (1957) 1 QB 159. 
what it does. It also has hands which hold the tools and act in accordance with directions from the centre. Some of the people in the company are mere servants and agents who are nothing more than hands to the work and cannot be said to represent the mind or will. Others are directors and managers who represent the directing mind and will of the company, and control what it does..."

This method has been applied to prosecute corporations for deaths caused by corporate activities. It was used in the prosecution following the collapse of the Herald of Free Enterprise, H.M. Coroner for Kent, Exp. Spooner, ${ }^{31}$ and the case of Attorney General's Reference (No. 2 of 1999) ${ }^{32}$ which followed the Southall rail crash where seven people were killed. In the same vein, Transco was prosecuted using this method for the gas explosion tragedy in Scotland. ${ }^{33}$ However, it has proved inadequate in determining the mens rea of large corporations. This is because in large corporations, the directing mind might not be easily linked with the actions constituting the crime. Therefore, the prosecution of the three cases cited above were unsuccessful because the directing mind could not be linked with the acts constituting the crime. In Transco's case, the prosecution failed because there was no evidence of negligence on the part of the directing mind of the corporation. Another shortcoming of this method is that it does not capture the reality of corporate crimes where crimes are committed more as a result of systemic process and not as a result of a deliberate act by a specific person. However, the identification method was used to successfully prosecute OLL Ltd., following a canoeing accident which killed four children. ${ }^{34}$ The corporation in this case was however a small one man company, therefore, it was easy to attribute the crime with the directing mind.

Another method of determining the corporate mens rea is through locating the corporate culture. It was developed in Australia as a statutory

\footnotetext{
$31 \quad$ (1989) 88 Cr. App. R. 207.

$32 \quad$ (2000) 2 Cr. App. R. 207.

33 Transco P.L.C v. H.MAdvocate (2003) G.W.D 38-1039, (2004) S.L.T, 995.

$34 \quad$ Rv. Kite \& OLL Ltd. (1994) 99 Cr. App. R. 362.
} 
response to violations of federal crimes. ${ }^{35}$ It has however not been subject to much judicial interpretation even in Australia. This method was introduced in the Australian Criminal Code Act $1995^{36}$ and it locates the corporate mens rea in the corporate ethos or standard, corporate policies, culture, practices and management. The corporate culture is defined in Section 6 as the attitude, policy rules and course of conduct or practise existing in a corporation. It further provides ${ }^{37}$ that the mens rea of an offence is attributed to a corporation that has expressly, impliedly or tacitly permitted or authorised the offence, and the existence of a corporate culture that tolerated or permitted the offence can be used to determine whether a corporation gave implied or tacit permission. ${ }^{38}$

It has been said that the rationale for corporate culture as a method of determining the corporate mens rea is that the policies, practices and culture of the corporation are evidence of corporate aims and intentions which developed from the decision making process of the company. ${ }^{39}$ This method is a good way of determining the corporate mens rea because liability is personal and not derivative and only a truly blameworthy corporation will be liable. However, as stated earlier, this method of determining the corporate mens rea has not been subjected to much judicial interpretation and it deals generally with corporate criminal liability generally and not corporate liability for homicide.

\section{THE EXPERIENCE IN NIGERIA}

This segment discusses the experience in Nigeria with specific reference to the two major sources of criminal law in Nigeria: the Criminal Code and the Penal Code.

\footnotetext{
35 Australia is a Federal state, the powers of the Commonwealth to legislate on criminal matters is limited to some specific federal offences. Part 2.5. 12.3(1). 12.3(2).

Field and Jong, (1991) “Corporate Manslaughter and Liability: Should we be Going Dutch” Crim. L.R., 156 at 159.
} 


\section{Criminal Code $e^{40}$}

Under the Criminal Code, chapter 27 deals with homicide, Section 306 of the Code provides that it is unlawful for a person to kill another except in circumstances justified, authorised or excused by law. It provides further in section 308 that whenever a person directly or indirectly caused the death of another, subject to other provisions in the chapter, such a person is deemed to have caused the death of such other person. Section 315 also provides ${ }^{41}$ that it is the circumstances in which death occurs that determine whether the offence is murder or manslaughter. It goes further in section 317 to give a comprehensive list of instances when the offence of murder will be said to have been committed. The instances are:

a) when a person intended to kill the deceased or any other person;

b) when a person intended to cause grievous harm to the deceased or any other person. This is irrespective of the fact that he did not intend to kill the deceased;

c) if the death of the deceased occurred as a result of the action of the person done in furtherance of an unlawful purpose irrespective of the fact that he did not intend to hurt any person;

d) if the person intended to do grievous harm in order to facilitate the commission of an offence of such a nature that an arrest could be made without warrant. It is immaterial that the person did not intend to cause death or know that death was likely to occur;

e) if a person caused the death of another through the application of any stupefying or overpowering substance for either in furtherance of an unlawful purpose or to facilitate the commission of an offence of such a nature that an arrest without warrant

40 Cap C38, L.F.N 2004. It is applicable in the southern part of Nigeria.

$41 \quad$ Section 315. 
could be made. This is irrespective of the fact that the person had no intention to cause death or knew that death was likely to occur; or

f) If a person wilfully stopped the breath of another for either of such purposes. It does not matter that the person/accused did not intend to cause death or knew that death was likely to occur.

The Criminal Code also defines manslaughter in section 317 as when a person unlawfully kills another in such a circumstance that does not constitute murder. Therefore, all other circumstances in which deaths occur apart from that expressly provided in section 316 shall suffice as manslaughter.

From the provisions of sections 316 and 317 above, although corporate manslaughter is not expressly stated in the Criminal Code, corporate homicide qualifies as a form of manslaughter.

\section{Penal Code $e^{42}$}

Under the Penal Code, the words "murder" and "manslaughter" are unknown. What is recognised under this Code is the offence of culpable homicide punishable with death and culpable homicide not punishable with death depending on the circumstances.

Section 220 defines culpable homicide as when death is caused in any of three instances:

a) If an act is done with the intention of causing death or inflicting bodily harm that can cause death;

b) If an act is done knowing that it is likely to cause death;

c) Or by doing a rash or negligent act.

42 As stated earlier, this is the main legislation on criminal law operative in the northern part of Nigeria. 
The Code goes further in section 221 to state the instances under which culpable homicide shall be punishable with death. The first is when the act is done with the deliberate intention to cause death. Secondly, if the accused knew or ought to know that death will be the probable and likely consequence of his act.

From the above, corporate homicide cannot be a type of culpable homicide punishable with death. This is because, as explained earlier in this paper, corporate activities resulting in death are usually caused as a result of negligent acts. Corporate homicide therefore can be accommodated under paragraph 220(c) of the Penal Code which is when death occurs as a result of a rash or negligent act.

Section 222 of the Code list instances of when culpable homicide will not be punishable with death as follows:

1. When death occurs as a result of grave provocation where the accused had lost his self- control or when death occurs by accident or mistake;

2. When the accused, acting in good faith in exercising his right to defend himself or his property, exceeds the power given to him and causes the death of another;

3. Where a public servant (or persons who aid a public servant) acts in good faith in the line of duty, but has exceeded the powers given to him to promote public justice;

4. When death occurs in the cause of a sudden fight and in the heat of passion; or

5. When a person causes the death of another by doing a rash or negligent act. ${ }^{43}$

The cumulative effect of the above provisions of the Penal Code is that corporate homicide qualifies as a type of culpable homicide not punishable with death. Thus, the definitions of corporate homicide and manslaughter

$43 \quad$ Section 222 (5) and (6) relates to suicide and infanticide. 
in both the Penal and Criminal Codes respectively encompass the common law offences of gross negligence, manslaughter and unlawful act manslaughter. The offence can be manslaughter or culpable homicide not punishable with death depending on the jurisdiction in Nigeria.

\section{The Criminal Code}

The words actus reas and mens rea are not expressly provided under the Code. Nevertheless, the Act recognises that there must be both physical and mental elements to a crime. The courts however often make reference to the common law terms of mens rea and actus reas. ${ }^{44}$ For example, in Abeke v. State, ${ }^{45}$ it was held that mens rea means a guilty mind. ${ }^{46}$

Chapter five of the Criminal Code deals with criminal responsibility and it provides in Section 24 thus:

"Subject to the express provisions of this code relating to negligent acts and omissions, a person is not criminally liable for an act or omission, which occurs independently of the exercise of his will, or for an event which occurs by accident.

Unless, the intention to cause a particular result is expressly declared to be an element of the offence constituted, in whole or part, by an act or omission, the result intended to be caused by an act or omission is immaterial. Unless otherwise expressly declared, the motive by which a person is induced to do or omit to do an act, or to form an intention, is immaterial so far as regards criminal responsibility.”

\footnotetext{
$44 \quad$ This is mainly due to the influence of the common law in Nigeria being a former British colony. These common law terms have imported into the Nigerian criminal law through the doctrine of judicial precedent.

45 (2007) 9 N.W.L.R Pt. 1040, 411 at 429-430.

$46 \quad$ Similarly in Mandillas \& Karaberies v. I.G.P (1958) 3 F.S.C. 20, the court relied on the common law principle of mens rea.
} 
The above explains criminal responsibility under the Code. First, the physical element is recognised to be in the form of an act or omission. Secondly, the requirement for the mental element is explained in three ways as follows. The first paragraph means that there can be no liability without fault. The word "will” in the paragraph means the accused's intention and awareness of the circumstances connected to the act. ${ }^{47}$ The second paragraph provides for result offences and simply denotes the common law rule on presumption of mens rea that unless intention is expressly stated as part of the definition of an offence, it is immaterial that the accused intended to cause a different result. Also, the wordings of section 24 show a presumption against vicarious liability for a mental element; it states that a person is said not to be liable for an act which occurs without the exercise of his will. This is in tandem with the principle that personal liability is the hallmark of criminal responsibility. ${ }^{48}$ Therefore, from these provisions, the mens rea or mental element is recognised; it is a matter of semantics that the common law phrase is not used expressly.

\section{Penal Code}

Under the Penal Code, the words mens rea and actus reas are also not expressed. The Penal Code is also couched in a different way from the Criminal Code. However, it provides in Chapter Two for criminal responsibility and its provisions also show that the principle of no liability without fault is recognised. Words like intention, knowledge, fraudulently and dishonestly are used to depict the mental element in the Penal Code. Section 48 provides:

"Nothing is an offence which is done by accident or misfortune and without any criminal intent or knowledge in the course of doing a lawful act in a lawful manner by lawful means and with proper care and caution" 49

\footnotetext{
$47 \quad$ Ali, p. 101.

48 Section 25 however provides that mistake of fact will be a defence to criminal responsibility unless the law creating a particular offence states otherwise.

$49 \quad$ The emphasis is mine.
} 
It is submitted that the reference to "proper care and caution" means without negligence. Intention, knowledge and negligence are used in the above provision to denote the mental element. Similarly, section 51 also provides that:

"Nothing is an offence which is done by a person who, at the time of doing it, by reason of unsoundness of mind, is incapable of knowing ${ }^{50}$ the nature of the act, or that he is either wrong or contrary to law."

Also, the principle of no liability without fault is recognised in the Penal Code. Therefore, although the terms actus reas and mens rea are not expressly used in both the Criminal and Penal Codes, however, both legislations recognise that there must be a physical and mental element to criminal liability. ${ }^{51}$

\section{CORPORATE LIABILITY FOR HOMICIDE UNDER THE CRIMINAL AND PENAL CODES}

As earlier stated, the Nigerian criminal law legislations recognise the principle of no liability without fault; the challenge of corporate liability for homicide is therefore in attributing the corporate body with the mental element.

In addition, the offence of corporate homicide is unknown in the Nigerian criminal laws. However, the challenge is whether the existing legal framework is sufficient to accommodate corporate homicide. The answer is in the negative because of the following reasons:

First, based on the provisions on criminal responsibility under the two Codes, mental element is fundamental to criminal liability except when otherwise stated in the Codes.

Secondly, based on the definition of the offences of manslaughter and culpable homicide not punishable with death in the Criminal and Penal Codes, a mental element is required as an element of the offence.

\footnotetext{
$50 \quad$ The emphasis is mine.

51 Except in the circumstances stated otherwise in the two Codes.
} 
Therefore, the mental element of a corporation must be determined for the purpose of holding it liable for homicide.

The Penal and Criminal Codes are silent on the issue of the mental element of an offence by a corporation. Also, the wording of the two Codes on the definition of the offence implies that a natural person was intended by the drafters. This is not surprising because the Codes are more than fifty years old. It seems therefore that the drafters did not envisage that a corporate body will be liable for an offence that requires mens rea. ${ }^{52}$

There is a dearth of cases involving prosecution of corporate bodies beyond that of strict liability regulatory offences. For example, in Adeyemo Abiodun \& Ors. v. F.R.N, ${ }^{53}$ a pharmaceutical company manufactured a teething mixture with a toxic substance which killed more than eighty children until February 2009 in Nigeria. The company together with three of its officials were prosecuted and convicted for breach of a statutory offence under the Miscellaneous Offence Act. ${ }^{54}$ The company was specifically charged under section 1(18) a(ii) which was a strict liability offence..$^{55}$

Another approach used in criminal prosecution of corporations is by lifting the corporate veil and prosecuting individual members or officers of a corporation. For example, in F.R.N v. Odogwu \& Anor No. $1,{ }^{56}$ involving a prosecution before the then failed bank tribunal, the corporate veil was lifted and the managing director of the bank was convicted. ${ }^{57}$

However, the identification theory is used in determining the corporate mens rea in civil cases. For example, in Bank for Commerce and Industry v. Integrated Gas (Nig.) Ltd, ${ }^{58}$ the Court of Appeal held

52 Corporate criminal liability for strict liability has been recognised much earlier in Nigeria.

53 Suit No. CA/L/550/M/2013.

$54 \quad$ M17, L.F.N 2004.

55 The company was convicted and wound up.

$56 \quad$ (1997) 1 FBTLR 179.

$57 \quad$ K.O Akanbi, (2012), Perspectives on the Legacy of Salomon v. Salomon on the Nigerian and Malaysian Company Laws, 1 LNS(A)I viii PAGE.

$58 \quad$ Ibid n.49, a similar decision was reached in Delta Steel (Nig) v. American Computer Technology Incorporated (1999) 4 NWLR pt.597, p. 53, C.A. 
that the state of mind of the directing mind and will of the company was the state of mind of the company.

\section{THE EXPERIENCE IN THE UNITED KINGDOM (UK)}

This section discusses the experience in the UK with particular reference to the Corporate Manslaughter and Corporate Homicide Act of 2007. The Corporate Manslaughter and Corporate Homicide Act 2007 is the first legislation on corporate homicide. The Act was passed essentially to solve the problems of the identification theory ${ }^{59}$ and was influenced by the general public outcry which followed the failed prosecution of the Herald of Free enterprise and Transco's case in Scotland. Therefore, it was also aimed to ensure more prosecutions. ${ }^{60}$

The Act therefore is a short Act and creates only the single offence of corporate homicide. ${ }^{61}$ Therefore, it addresses the challenges of determining the corporate mens rea. Section 1(1) defines the offence as when the way in which the activities of an organisation is managed or organised causes the death of a person and also constitute a gross breach of duty of care owed by the organisation to the deceased victim.

From the provisions of Section 1(1), it is fundamental that the death that occurred must have been as a result of a breach of a duty of care. The corporation must owe the deceased a duty of care which must have been breached. ${ }^{62}$

By the above definition of the offence, the actus reas of the offence is therefore acts or omissions which constitute the activities of the corporation. ${ }^{63}$ Therefore, acts or omissions of officers or agents of a corporation acting within the apparent and implied scope of employment,

\footnotetext{
$59 \quad$ Hansard December 19, 2006, HL, col 1896 \& 1898.

$60 \quad$ Home Office “Corporate Manslaughter: The Government’s Draft Bill for Reform (CM 6497) March 2005, pp 8-9.

61 Corporate Homicide in Scotland and Corporate Manslaughter in other parts of England.

62 Section 2 gives a comprehensive instance of duty of care and is based on the duties owed under the law of negligence.

63 Or organisation as used in the Act.
} 
done while carrying out the usual business of the corporation shall be regarded as the acts and omissions of the corporation itself.

\section{Mens Rea Under The Act}

The mens rea or mental element is vested in the management hierarchy of the corporation. Section 1(3) explains that a corporation cannot be convicted of the offence unless the way in which its activities are managed or organised by its senior management is a substantial element in the breach of duty of care.

Section 1(4) c defines senior management as a person who plays a significant role in the decision making of the whole or substantial part of the corporation. ${ }^{64}$ At the first glance, it seems that this is a passive reference to the identification theory because the senior management looks more or less like the directing mind. However, the combined effect of Section 1(3) and (4) allows a broader approach to the identification method because it aggregates the activities of management and not just one or two directing minds. Also, the way the activities of a corporation are managed can actually reflect both the written and unwritten rules of a corporation.

Besides, unlike the identification theory, a corporation that has taken steps to prevent the death will escape liability under the Act. Section 1(4)b provides that a breach of a duty by a corporation qualifies as gross breach if the conduct alleged falls far below ${ }^{65}$ what is reasonably expected of such corporation. This aptly captures the corporate mens rea and only a truly guilty corporation will be liable.

The provision of Section 8(3) is also instructive. It provides for factors for the jury to consider in determining whether there has been a gross breach of duty of care by the corporation. It provides that the jury should consider the attitudes, policies, accepted practices and systems within the organisation that encouraged the act constituting the breach of duty of care. It is submitted that the corporate mens rea can in fact be located in the unwritten rules, attitudes and practices of a corporation.

\footnotetext{
64 As stated earlier, the word "organization" is used in the Act.

65 Emphasis mine.
} 
It can be said that the Corporate Manslaughter and Corporate Homicide Act is a bold attempt at providing a legal framework for holding corporations liable for death which occurs as a result of corporate activities. It has therefore provided the method of attributing the criminal law ingredients of actus reas and mens rea to a corporation.

\section{CONCLUSION}

An adequate and dependable legal framework for dealing with corporate activities leading to death is imperative in order to ensure that corporations take more care in the performance of their duties and become more responsible to their workers, consumers and the general public who are affected by corporate activities. Yet, the legal framework is not adequate enough to make corporations criminally liable for their actions and inactions leading to death. Consequently, corporations are either unpunished or inadequately sanctioned for their deeds and misdeeds. So, more crimes seem to be committed by corporations on a daily basis. This is despite the fact that the locus classicus case of Salomon $v$ Salomon created a corporate entity that could sue and be sued. Nevertheless, the major obstacle or challenge in the way of justice in this regard is the application of actus reas and mens rea to corporation. This therefore makes it easy for the corporation to escape criminal liability. This is despite the fact that corporate activities resulting in death are usually from negligent acts.

The experience in Nigeria highlights an inadequate legal framework for making corporations liable for homicide. This is because the criminal justice system does not recognise the offence of corporate homicide. Also, proving the element of mens rea is a difficult task in the court. Nonetheless, the UK criminal justice system in relation to corporations presents a good model for Nigeria. The reason is that first, the UK law, as discussed above, recognises the offence of corporate homicide. The law also liberalises the proof regarding the element of means rea as far as corporations are concerned. This perhaps makes the corporations in UK adopt best corporate practices for preventing avoidable incidences of corporate homicide. So, the bold and ambitious Corporate Manslaughter and Corporate Homicide Act of the UK is a step in the right direction. It is thus suggested that the supposed impediments of attributing the actus reas and mens rea to an artificial 
entity can be overcome. Thus, corporations should be held liable for deaths whether of consumers, workers or the general public which occur as a result of corporate activities. 